NOTE

\title{
Vibrio alginolyticus associated with white spot disease of Penaeus monodon
}

\author{
Joseph Selvin ${ }^{1, *}$, A. P. Lipton ${ }^{2}$ \\ ${ }^{1}$ Department of Biotechnology, Malankara Catholic College, Mariagiri, Kaliakavilai 629 153, Kanyakumari District, India \\ ${ }^{2}$ Marine Biotechnology Laboratory, Central Marine Fisheries Research Institute, Vizhinjam 695 521, \\ Thiruvananthapuram, India
}

\begin{abstract}
In February 2000, white spot disease outbreaks occurred among cultured Penaeus monodon in extensive shrimp farms on the southwest coast of India. Bacteria were isolated from infected shrimp that showed reddish body coloration and white spots in the cuticle. The isolates were screened on thiosulfate citrate bile salt sucrose (TCBS) agar plates for the selection of Vibrio species. The primary isolate (QS7) was characterized as $V$. alginolyticus based on morphological, biochemical and physiological characteristics. Antibiotic sensitivity tests of QS7 indicated that the isolate was highly sensitive to chloramphenicol, ciprofloxacin, nalidixic acid and streptomycin. Pathogenicity tests confirmed that the isolate was virulent for $P$. monodon. Based on the lethal dose $\left(\mathrm{LD}_{50}\right)$ value $(5 \times$ $10^{6} \mathrm{cfu}$ per shrimp), it was inferred that shrimp weakened by white spot syndrome virus would succumb to secondary infection by QS7.
\end{abstract}

KEY WORDS: Bacterial disease $\cdot$ Penaeus monodon $\cdot$ Secondary pathogen $\cdot$ Vibrio $\cdot$ Antibiogram • Pathogenicity

Resale or republication not permitted without written consent of the publisher

\section{INTRODUCTION}

Vibriosis has been implicated as the cause of major mortality in juvenile penaeid shrimp (Lightner \& Redman 1994). Disease caused by Vibrio alginolyticus and $V$. harveyi remains a serious problem in cultured black tiger shrimp in India, being overshadowed only by white spot syndrome virus (WSSV) infections, which cause even more serious problems throughout Asian countries. Vibrio species are among the normal bacterial flora of both natural and cultural populations of shrimp and the culture environment (Jiravanichpaisal et al. 1994, Otta et al. 1999), but often act as opportunistic or secondary pathogens that can cause mortality ranging from a few to $100 \%$ in affected populations under stress (Lightner 1988).

In February 2000, an outbreak of white spot disease among Penaeus monodon led to mortalities that culminated in the termination of grow-out activities

*Email: selvinj@rediffmail.com after $60 \mathrm{~d}$ of culture (DOC) in extensive shrimp farms in and around the Quilon area (southwest coast of India). Infected shrimp exhibited white spots in the cuticle together with reddish patches on the shell and tail areas, indicating secondary bacterial infections (Karunasagar et al. 1997). The characteristic red patches were not observed in apparently healthy specimens. Therefore, the present study was initiated to identify secondary pathogens and to test their virulence by experimentally infecting healthy shrimp. In addition, we determined antibiotic sensitivity for possible therapeutic treatment.

\section{MATERIALS AND METHODS}

Biochemical characterization and antibiograms of isolated bacteria. The farm from which we collected samples covered an area of 0.6 ha and was stocked 
with 100000 black tiger shrimp Penaeus monodon. The average body weight of the infected shrimp was $14.6 \pm 1.23 \mathrm{~g}$ on the day of sampling (60 DOC). The culture conditions on the farm included $\sim 25 \%$ daily water exchange and a pelleted feed provided at a rate of $3.2 \%$ of shrimp body weight $\mathrm{d}^{-1}$. Shrimp (50) showing signs of white spots and red coloration were collected and transported to the laboratory in circular, $250 \mathrm{l}$ volume, high-density plastic tanks provided with constant aeration. The prevalence of WSSV was confirmed with a commercial PCR-based WSSV detection kit (Genei). After recording their sizes, the shrimp were examined externally using standard methods (Austin \& Austin 1989). Initial bacterial isolations were made from infected shells and hepatopancreatic tissue. The infected shell area was removed with sterile scissors and swabbed onto plates of nutrient agar supplemented with $2 \% \mathrm{NaCl}$ (NA). Hepatopancreatic tissue was homogenized in a sterile homogenizer (Omni) using normal saline (NS). The resultant suspension was serially diluted up to $10^{-6}$ with phosphate-buffered saline and used for preparation of spread plates on NA. The plates were incubated at $32 \pm 2^{\circ} \mathrm{C}$ for $18 \mathrm{~h}$. Dominant colonies observed on the NA plates were further screened on thiosulfate citrate bile salts sucrose (TCBS) agar (Himedia). Thus, 7 yellow colonies observed were further screened for O/129 (Sigma) resistance using impregnated $(150 \mu \mathrm{g})$ paper discs (8 mm diameter).

Colony morphology was observed at $18 \mathrm{~h}$, and cell shape was recorded after Gram staining followed by observation at $1000 \times$ magnification. Biochemical tests followed the methods of MacFaddin (1981). All test media were supplemented with $2 \% \mathrm{NaCl}(\mathrm{w} / \mathrm{v})$. Tests for chitinase, amylase, caesinase and gelatinase were based on those of Cowan (1974) and Austin \& Lee (1992). The $\beta$-galactosidase test was done with $o$ nitrophenyl beta-D-galactopyranoside (ONPG) disks (HiMedia). Results were recorded after incubation at $30 \pm 2{ }^{\circ} \mathrm{C}$, and incubation time depended on each test. The effect of $\mathrm{NaCl}$ concentration and temperature on growth was also tested. Bacterium (QS7) identification followed the descriptions of Baumann \& Schubert (1984) and Colwell \& Grimes (1984). Antibiotic sensitivity profile was determined by the Kirby-Bauer diskdiffusion method (Bauer et al. 1996) using HiMedia antibiotic discs. The isolate was considered sensitive to a particular antibiotic when the zone of inhibition equalled $8 \mathrm{~mm}$.

Pathogenicity and $\mathbf{L D}_{\mathbf{5 0}}$. Healthy juvenile Penaeus monodon (40 DOC) were selected from grow-out tanks of the Marine Biotechnology Laboratory (India) aquarium and maintained at 10 shrimp per tank in $100 \mathrm{l}$ glass aquaria at $30 \pm 2{ }^{\circ} \mathrm{C}$. The length and weight of each shrimp were measured before starting the experiment.
Prior to challenge experiments, the shrimp were sampled for the presence of bacteria to ensure that they were pathogen-free. A slant culture was activated in nutrient broth supplemented with $2 \% \mathrm{NaCl}$ and subcultured in fresh media. An 18 h shake-culture was centrifuged at $4800 \times g$ for $15 \mathrm{~min}$. Cell pellets were washed twice with NS, re-suspended and serially diluted in NS, and enumerated by plating on NA plates to obtain counts of colony-forming units (cfu). Preliminary examination revealed that a challenge dose of $10^{3} \mathrm{cfu}$ per shrimp was insufficient to cause mortality. Therefore, concentrations of $10^{5}$ to $10^{8} \mathrm{cfu}$ in $0.1 \mathrm{ml}$ NS were injected intramuscularly in the ventral side of each shrimp between the second and third segment using a $1 \mathrm{ml}$ tuberculin syringe. Parallel control groups received $0.1 \mathrm{ml}$ of $\mathrm{NS}$ only; 10 shrimp were used at each challenge level. The mortality and behavior of the shrimp were observed every 15 min during the first hour post-injection (p.i.) and every $1 \mathrm{~h}$ thereafter until Hour 6 p.i. Subsequent monitoring was done every $12 \mathrm{~h}$ for a period of $7 \mathrm{~d}$ (Tendencia \& Dureza 1997). Hepatopancreatic tissue homogenate of moribund shrimp was used for the reisolation of bacteria using Zobell marine agar (HiMedia Manual 1998) plates. The $\mathrm{LD}_{50}$ doses for $24 \mathrm{~h}$ and $7 \mathrm{~d}$ were calculated by the probit method, after Wardlaw (1985).

\section{RESULTS}

\section{Biochemical characteristics of isolates}

Bacteriological isolation revealed that the shrimp were infected with a single type of bacterium. Although initially the isolates were recorded as 7 different colonies, biochemical characteristics revealed their similarity. All 50 shrimp showed characteristic WSSV infection. Bacteriological isolation on the TCBS agar plates revealed that only 30 shrimp contained characteristic yellow colonies. Therefore, the prevalence of dual Vibrio alginolyticus and WSSV infection in the pond was assumed to be $\sim 60 \%$. The characteristics of the chosen isolate (QS7) are shown in Table 1. Based on this and comparison with earlier reports, the isolate was identified as V. alginolyticus (QS7) (Lee et al. 1996).

\section{Antibiogram}

QS7 was highly susceptible to chloramphenicol, ciprofloxacin, nalidixic acid and streptomycin with inhibition zones of 35, 30, 31 and $30 \mathrm{~mm}$, respectively. Inhibition zones for gentamycin, metronidazole, rifampicin, erythromycin and ampicillin were $10 \mathrm{~mm}$. The isolate was resistant to penicillin-G and bacitracin 
and completely unaffected by oxytetracyline, a commonly used shrimp therapy. Sulphamethizole was grouped amongst the least active antibiotics because resistant colonies were observed inside the inhibition area. This also occurred with sulphadiazine, tetracycline, trimethaprim, cloxacillin, amoxycillin and amphotericin-B.

Table 1. Vibrio alginolyticus. Characteristics of bacterium (QS7) isolated from diseased Penaeus monodon. +: positive; -: negative; TCBS: thiosulfate citrate bile salts sucrose agar; ONPG: o-nitrophenyl beta-D-galactopyranoside

\begin{tabular}{|c|c|}
\hline Test/characteristic features & QS7 \\
\hline Gram staining & - \\
\hline Shape & Short rod \\
\hline Growth on TCBS & Green \\
\hline Sensitivity to vibriostatic $0 / 129$ phosphate & + \\
\hline Luminescence & - \\
\hline Swarming & + \\
\hline Oxidase production & + \\
\hline Catalase production & + \\
\hline Oxidative-fermentive test & + \\
\hline \multicolumn{2}{|l|}{ Acid/gas production: } \\
\hline Glucose & Acid \\
\hline Sucrose & Acid \\
\hline Mannitol & Acid \\
\hline Maltose & Acid \\
\hline Sorbitol & - \\
\hline Lactose & - \\
\hline Galactose & - \\
\hline Arabinose & Acid \\
\hline Nitrate reduction & + \\
\hline Methyl red & + \\
\hline Voges-Proskauer & + \\
\hline Indole production & - \\
\hline Hydrogen sulfide production & - \\
\hline ONPG hydrolysis & - \\
\hline \multicolumn{2}{|l|}{ Decarboxylase of: } \\
\hline Arginine & - \\
\hline Lysine & + \\
\hline Ornithine & + \\
\hline \multicolumn{2}{|l|}{ Growth in: } \\
\hline $4^{\circ} \mathrm{C}$ & - \\
\hline $40^{\circ} \mathrm{C}$ & + \\
\hline \multicolumn{2}{|l|}{ Growth in peptone with $\mathrm{NaCl}$} \\
\hline $0 \%$ & - \\
\hline $0.5 \%$ & - \\
\hline $1 \%$ & + \\
\hline $3 \%$ & + \\
\hline $6 \%$ & + \\
\hline $8 \%$ & + \\
\hline $10 \%$ & + \\
\hline \multicolumn{2}{|l|}{ Production of exo-cellular enzymes: } \\
\hline Amylase & + \\
\hline Caesinase & + \\
\hline Gelatinase & + \\
\hline Chitinase & + \\
\hline Urease & - \\
\hline
\end{tabular}

Table 2. Vibrio alginolyticus (QS7). Pathogenicity to Penaeus monodon, based on triplicate trials

\begin{tabular}{|lcccc|}
\hline $\begin{array}{l}\text { Dose (cfu } \\
\text { per shrimp) }\end{array}$ & $\begin{array}{c}\text { Length } \\
(\mathrm{cm})\end{array}$ & $\begin{array}{c}\text { Weight } \\
(\mathrm{g})\end{array}$ & $\begin{array}{c}\text { Mortality } \\
(\%)\end{array}$ & $\begin{array}{c}\text { Infection } \\
(\%)\end{array}$ \\
\hline $10^{8}$ & $6.50 \pm 0.15$ & $2.60 \pm 0.52$ & 100 & 0 \\
$10^{7}$ & $6.26 \pm 0.18$ & $2.38 \pm 0.16$ & 80 & 20 \\
$10^{6}$ & $6.28 \pm 0.42$ & $2.42 \pm 0.23$ & 20 & 80 \\
$10^{5}$ & $5.96 \pm 0.62$ & $2.12 \pm 0.28$ & 0 & 30 \\
$10^{4}$ & $6.42 \pm 0.13$ & $2.48 \pm 0.18$ & 0 & 0 \\
\hline
\end{tabular}

\section{Pathogenicity and $\mathrm{LD}_{50}$}

At a high dose $\left(10^{8} \mathrm{cfu}\right.$ per shrimp), all shrimp died at 6 to $24 \mathrm{~h}$ p.i. (Table 2). No mortality was observed within $7 \mathrm{~d}$ p.i. at $10^{5} \mathrm{cfu}$ per shrimp, although infections were noticed on Day 5. The $\mathrm{LD}_{50}$ value extrapolated from the graph was $5 \times 10^{6} \mathrm{cfu}$ per shrimp. Signs of infection included brown or black spots on the shell, darkened or red body surface, pink or brown gills, murky whitish muscle, a lack of food in the midgut, and a folded base of the tail.

\section{DISCUSSION}

The diseased shrimp collected from the farm were under stress due to high stocking density (160000 ha ${ }^{-1}$ ) and subsequent deterioration of hydrological conditions from high feed inputs and accumulation of organic matter on the pond bottom. Such conditions usually develop in the middle of the shrimp culture period (de la Pena et al. 1992). Severe stress and injury to the shrimp under poor environmental conditions lowers their resistance (Liu 1990), rendering them susceptible to viral as well as bacterial infection (Sindermann 1990).

In addition, the primary WSSV infection probably weakened the shrimp and made them more susceptible to bacterial infection. The isolation of such secondary pathogens from outbreaks of WSSV in cultured tiger shrimp and consequent mass mortality has been reported in Taiwan (Lee et al. 1996). The WSSVinfected shrimp showed reddish coloration in addition to the white spots in the cuticle. According to Karunasagar et al. (1998), reddish coloration of WSSVinfected shrimp could be attributable to secondary bacterial infection.

According to an earlier report, a virulent pathogenic strain of Vibrio alginolyticus isolated from WSSVinfected shrimp was sensitive to chloramphenicol, ciprofloxacin, nalidixic acid, oxolinic acid, penicillinG, and sulfonamide (Lee et al. 1996). This sensitivity pattern resembled that observed for QS7 in the pre- 
sent study. Based on the QS7 results, it could be inferred that antibiotics such as ciprofloxacin, nalidixic acid and streptomycin might be useful therapy for WSSV-infected shrimp. However, because of emerging environmental and public health concerns, their usage has to be kept to a minimum.

Our pathogenicity tests confirmed that QS7 was virulent to shrimp. It has previously been reported that shrimp affected by WSSV become susceptible to invasion by environmental Vibrio species including $V$. alginolyticus (Karunasagar et al. 1997). V. alginolyticus has also been reported as a pathogen associated with shrimp diseases including 'black splinter disease' in Thailand (Ruangpan \& Kitao 1991). According to Ramasamy et al. (1995), mortality in Penaeus monodon infected with monodon baculovirus (MBV) was hastened by secondary bacteria. The bacteria might have entered the hepatopancreas as secondary pathogens via lesions resulting from MBV (Lightner et al. 1983).

Vibrio alginolyticus was isolated as a virulent secondary bacterial pathogen from shrimp infected with WSSV and was found to be lethal for Penaeus monodon and kuruma prawns $P$. japonicus, with $\mathrm{LD}_{50}$ values of $1.13 \times 10^{5}$ and $2.46 \times 10^{5} \mathrm{cfu} \mathrm{g}^{-1}$ shrimp, respectively (Lee et al. 1996). These values are in the range that we found for QS7. They are also similar to $\mathrm{LD}_{50}$ values $\left(1.1 \times 10^{6}\right.$ to $\left.2.2 \times 10^{7}\right)$ of $6 \mathrm{~V}$. alginolyticus strains isolated from a culture environment and used to challenge healthy $P$. monodon post-larvae (Otta et al. 1999). A virulent strain isolated from moribund kuruma prawns had an $\mathrm{LD}_{50}$ of $4.43 \times 10^{4} \mathrm{cfu} \mathrm{g}^{-1}$ shrimp (Lee et al 1996). The $\mathrm{LD}_{50}$ values in the present study indicated that the shrimp weakened by WSSV may die due to secondary bacterial infections.

Acknowledgements. The authors thank Dr. M. J. Modaiyl, Director and Dr. R. Paul Raj, Head, PNP Division, CMFRI, Cochin, for encouragement and use of facilities. This paper was part of the PhD thesis work of J.S.

\section{LITERATURE CITED}

Austin B, Austin DA (1989) Methods for the microbiological examination of fish and shellfish. Ellis Horwood, Chichester

Austin B, Lee JV (1992) Aeromonadaceae and Vibionaceae. In: Board RG, Jones D, Skinner FA (eds) Identification methods in applied and environmental microbiology. technical series of the society for applied bacteriology. Blackwell, Oxford, p 163-182

Bauer AW, Kirby WMM, Shenis JC, Turck M (1996) Antibiotic susceptibility testing by a standardized single disk method. Am J Clin Pathol 45:493

Baumann P, Schubert RHW (1984) Family U. Vibrionaceae. In: Krieg NR, Holt JG (eds) Bergey's manual of systematic bacteriology, Vol 1. Williams \& Wilkins, London, p 516-538

Editorial responsibility: Timothy Flegel,

Bangkok, Thailand
Colwell RR, Grimes JA (1984) Vibrio diseases of marine fish populations. Helgol Wiss Meeresunters 37:265-287

Cowan ST (1974) Cowan and Steel's manual for the identification of medical bacteria, 2nd edn. Cambridge University Press, London

de la Pena LD, Momoyama K, Nakai T, Muruga K (1992) Detection of the causative bacterium of vibriosis in kuruma prawn, Penaeus japonicus. Fish Pathol 27:223-228

HiMedia Manual (1988) HiMedia Manual for microbiology laboratory practice. HiMedia Laboratories, Mumbai

Jiravanichpaisal P, Miyasaki T, Limsuwan C (1994) Histopathology, biochemistry, and pathogenicity of Vibrio harveyi infecting black tiger prawn Penaeus monodon. J Aquat Anim Health 6:27-35

Karunasagar I, Otta SK, Karunasagar I (1997) Histopathological and bacteriological study of white spot syndrome of Penaeus monodon along the west coast of India. Aquaculture 153(1-2):9-13

Karunasagar I, Otta SK, Karunasagar J (1998) Monodon baculovirus (MBV) and bacterial septicemia associated with mass mortality of cultivated shrimp (Penaeus monodon) from the east coast of India. Indian J Virol 14(1):27-30

Lee KK, Yu SR, Yand TI, Liu PC, Chen FR (1996) Isolation and characterization of Vibrio alginolyticus from diseased kuruma prawn, Penaeus japonicus. Lett Appl Microbiol 22:111-114

Lightner DV (1988) Diseases of cultured penaeid shrimp and prawns. In: Sinderman CJ, Lightner DV (eds) Disease diagnosis and control in North American marine aquaculture, 2nd edn. Elsevier, Amsterdam, p 8-127

Lightner DV, Redman RM (1994) New and emerging infectious and non-infectious diseases in commercial shrimp culture. In: International Symposium on Aquatic and Animal Health. Programme and Abstracts, University of California, Davis, p V-3

Lightner DV, Redman RM, Bell TA (1983) Observation on the geographic distribution, pathogenesis and morphology of the baculovirus from Penaeus monodon Fabricus. Aquaculture 32:209-233

Liu CI (1990) The diseases of cultured Penaeus monodon with emphasis on recent discoveries in Taiwan In: Kou GH, Wakabayashi H, Liao IC, Chen SN, Lo CF (eds) Fish diseases. Proc R Jpn Symp. Taipei, Taiwan. NSC Symp Ser 16:180-201

MacFaddin JF (1981) Biochemical tests for identification of medical bacteria, 2nd edn. Williams \& Wilkins, Baltimore

Otta SK, Karunasagar I, Karunasagar I (1999 Bacterial flora associated with shrimp culture ponds growing Penaeus monodon in India. J Aquacult Trop 14(4):309-318

Ramasamy P, Breman GP, Jayakumar R (1995) A record and prevalence of Monodon baculovirus from postlarval Penaeus monodon in Madras, India. Aquaculture 130: 129-135

Ruangpan L, Kitao T (1991) Vibrio bacteria isolated from black tiger shrimp, Penaeus monodon Fabricious. J Fish Dis 14:383-388

Sindermann CJ (1990) Bacteria. In: Principal diseases of marine fish and shellfish, Vol 2. Academic Press, San Diego, p 41-74

Tendencia EVA, Dureza LA (1997) Isolation of Vibrio sp. from Penaeus monodon (Fabricius) with red disease syndrome. Aquaculture 154:107-114

Wardlaw AC (1985) Practical statistics for experimental biologists. John Wiley \& Sons, Chichester

Submitted: April 4, 2003; Accepted: September 6, 2003

Proofs received from author(s): October 27, 2003 